\title{
THE FAUNA OF BATS FROM THE UPPER PLEISTOCENE LOCALITY OF SANTENAY (CÔTE-D'OR, FRANCE)
}

\author{
Paloma SEVILLA*
}

\begin{abstract}
The bat fauna from the locality of Santenay (Burgundy, France) is described. This locality constitutes one of the richest in bat remains from the French upper Pleistocene. Eight species are represented in the material, five of which belong to the genus $M y o t i s, M$. bechsteini, $M$. nattereri, $M$. emarginatus, $M$. brandti and $M$. daubentoni. $M$. bechsteini is the dominating species. The two European Plecotus species are represented in Santenay by a high number of remains, whereas Barbastella barbastellus and Rhinolophus hipposideros have a low representation.

The association of bat species in Santenay is not common in the French Quaternary. The absence of termophilous species, together with the high percentage of mainly tree-dwelling species, indicates a relatively cold climate. The high diversity seems to indicate a change in the climate, most probably from a milder to a colder climate.
\end{abstract}

Key-words : Chiroptera, Upper Pleistocene, Santenay, France.

\section{RÉSUMÉ}

\section{LA FAUNE DE CHAUVE-SOURIS DU PLÉISTOCÈNE SUPÉRIEUR DE SANTENAY (CÔTE-D'OR, FRANCE)}

La faune de chauve-souris du gisement de Santenay (Bourgogne, France) est décrite. Ce gisement est un des plus riches en restes de chiroptères du Pléistocène supèrieur de France. Huit espèces sont présentes à Santenay, dont cinq appartiennent au genre $M y o t i s: M$. bechsteini, M. nattereri, M. emarginatus, $M$. brandti et $M$. daubentoni. M. bechsteini est l'espèce dominante. Les deux espèces de Plecotus européennes sont répresentées à Santenay par des nombreux restes, autant que Barbastella barbastellus et Rhinolophus hipposideros ont une pauvre répresentation.

L'association d'espèces de chiroptères à Santenay n'est pas habituelle dans le Quaternaire français. L'absence d'espèces thermophiles accompagné par une pourcentage elevée d'espèces fondamentalement arboricoles semble indiquer un climat relativement froid. La grande diversité observée pourrait être due à un climat de transition entre moins froid et plus froid.

Mots-clés : Chiroptères, Pleistocène supérieur, Santenay, France.

\section{RESUMEN}

Se describe la fauna de Quirópteros del yacimiento de Santenay (Borgoña, Francia), uno de los más ricos en restos de murciélagos dentro del Pleistoceno Superior francés. Ocho especies se encuentran representadas, cinco de ellas pertenecientes al género Myotis : $M$. bechsteini, $M$. nattereri, $M$. emarginatus, $M$. brandti y $M$. daubentoni, siendo $M$. bechsteini la más abundante en número de restos. Las dos especies europeas de Plecotus, están representadas en Santenay por numerosos restos. Barbastella barbastellus y Rhinolophus hipposideros se encuentran representadas por un número bajo de restos.

El tipo de asociación de especies hallada en Santenay no es habitual en el Cuaternario francés. La ausencia de especies termófilas y el alto porcentaje de representación de especies fundamentalmente arborícolas son indicativos de un clima relativamente frío. La alta diversidad parece indicar que la asociación proviene de una etapa de cambio climático, probablemente de menos frío a más frío.

Palabras clave : Quirópteros, Pleistoceno superior, Santenay, Francia.

*Departamento de Paleontología, Facultad de Ciencias Geológicas e Instituto de Geología Económica. Universidad Complutense. 28040 Madrid (Spain). 


\section{INTRODUCTION}

The upper Pleistocene locality of Santenay is located in an Upper Bathonian hill exploited to extract dolomitic material for glass industry. On the second half of last century it became known for containing fossil Vertebrate remains in different fissure fillings. Originally, the material extracted belonged mostly to large mammals : deer, horse, wolf, fox, a large felid, etc. Since then, several different excavations have been carried out in this locality in the hope of finding human industry. However, this search proved to be fruitless until 1961, when Dr. Chaline found several stone tools.

This same author is responsible for the first detailed study of the rich Micromammal fauna of Santenay, which is interpreted as coming from the Riss-Würm up to the beginning of the ancient Würm (Chaline, 1972). Together with abundant Rodents and Insectivores, a considerable amount of bat remains are to be found in the Santenay material. Though different layers and fissures were excavated, the bat remains were only found in the red interior limes («limons rouges interieurs»). Chaline (1972) mentions the presence of five different bat species : Rhinolophus hipposideros, Myotis daubentoni, Myotis nattereri, Myotis bechsteini and Plecotus auritus. In the study of the bat fauna we present here, not only mandibles and maxillae were considered, but also isolated teeth and humera. The presence in Santenay of the bat species mentioned by Chaline in 1972 is confirmed, as well as that of four other species, Myotis emarginatus, Myotis brandti, Plecotus austriacus and Barbastella barbastellus.

\section{MATERIAL AND METHODS}

Considering mandibles, maxillae, isolated teeth, humera and cochlea, the number of bat remains in Santenay is over five thousand. Due to the high

\begin{tabular}{ccccccc|}
$C^{*}$ & $n$ & $\bar{x}$ & $\min .-\max$. & $\sigma_{n-1}$ & $\Sigma \times 2$ \\
\hline$L$ & 106 & 1,09 & $1,01-1,18$ & 0,03 & 127,47 \\
$W$ & 108 & 0,93 & $0,81-1,07$ & 0,04 & 94,64 \\
\hline$P^{4}$ & 61 & 1,33 & $1,24-1,44$ & 0,05 & 109,19 \\
$M^{\prime}$ & 57 & 1,03 & $0,90-1,12$ & 0,04 & 61,27 \\
\hline$L$ & 68 & 1,61 & $1,49-1,70$ & 0,04 & 177,94 \\
$M^{2}$ & 72 & 1,64 & $1,44-1,97$ & 0,08 & 195,85 \\
\hline$L$ & 64 & 1,63 & $1,50-1,76$ & 0,05 & 172,00 \\
$W$ & 69 & 1,95 & $1,81-2,04$ & 0,05 & 263,13 \\
\hline$L$ & 76 & 0,99 & $0,84-1,12$ & 0,05 & 75,29 \\
$W$ & 80 & 0,91 & $0,85-1,04$ & 0,03 & 66,92 \\
\hline
\end{tabular}

number of remains, only mandibles, maxillae and certain teeth (canines, P4s and molars) were considered. The material, once identified on the basis of size and morphology was found to correspond entirely to recent species. The criteria used for the identification are described in Sevilla \& LópezMartínez (1986) and Menu \& Popelard (1987). More than $50 \%$ of the material was measured following Sigé (1968) and Sevilla (1989) (Tables 1-8). All the material represented in Plates 1-5 is from Santenay. The distribution of the different species in France, as well as their ecologic characteristics, used for the interpretations, were taken from Fayard (1986).

\section{DESCRIPTION OF THE FAUNA}

Myotis bechsteini (KUHL) is the largest and the most abundant of the species present in Santenay. In all, 1094 remains were identified as belonging to $M$. bechsteini. In this species, the $\mathrm{P}^{4}$ presents a short heel without anterolingual cusp on the cingulum. The upper molars present no paraloph, metaloph, paraconule nor metaconule, except in the $\mathrm{M}^{3}$, which presents paraloph. The upper canine is strong, the apex of its cusp is slightly bent distally and presents subequal labial and lingual furrows. The lower teeth present a thick cingulum. The $\mathrm{P}_{4}$ is rectangular in occlusal view, with a medial constriction. The coronoid process of the mandible is wide and rounded, considerably higher than the angular process. The mental foramen lies between the canine and $\mathrm{P}_{2}$. Myotis bechsteini, frequently found in Pleistocene localities of Europe is a species which is becoming rare in the present. It is distributed all over France, especially in woody areas. It can be found roosting both in caves and in trees.

Myotis nattereri (KUHL) is another species abundantly represented in Santenay (736 remains). This species is somewhat smaller than $M$. bechsteini, but

\begin{tabular}{lllllll|}
\multicolumn{1}{c}{$n$} & $\bar{x}$ & min. - max. & $\sigma_{n-1}$ & $\sum x^{2}$ \\
\cline { 2 - 6 } & $P_{4}$ & 46 & 0,97 & $0,89-1,05$ & 0,03 & 43,56 \\
$W$ & 44 & 0,73 & $0,64-0,80$ & 0,03 & 23,94 \\
\hline$L$ & 71 & 1,52 & $1,42-1,63$ & 0,04 & 165,01 \\
$M_{1}$ & $M_{2}$ & 77 & 0,96 & $0,87-1,11$ & 0,05 & 71,37 \\
$W_{2}$ & 73 & 1,06 & $0,95-1,18$ & 0,04 & 83,23 \\
\hline$L$ & 55 & 1,55 & $1,47-1,67$ & 0,04 & 133,45 \\
$W_{1}$ & 57 & 1,04 & $0,95-1,14$ & 0,04 & 61,83 \\
$W_{2}$ & 58 & 1,11 & $1,01-1,23$ & 0,04 & 72,81 \\
\hline$L$ & 50 & 1,41 & $1,34-1,49$ & 0,03 & 99,67 \\
$W_{1}$ & 53 & 0,98 & $0,88-1,11$ & 0,05 & 51,50 \\
$W_{2}$ & 52 & 0,75 & $0,62-0,84$ & 0,04 & 29,58 \\
\hline
\end{tabular}

Table 1. - Measurements, in mm, of the teeth of Myotis bechsteini from Santenay. 


\begin{tabular}{lllllll|}
\multicolumn{1}{c}{$n$} & $\bar{x}$ & $\min .-\max$. & $\sigma_{n-1}$ & $\Sigma x^{2}$ \\
\hline$L$ & 95 & 0,98 & $0,86-1,12$ & 0,04 & 92,88 \\
$C^{\circ}$ & 94 & 0,73 & $0,62-0,94$ & 0,05 & 50,40 \\
\hline$L$ & 39 & 1,14 & $1,00-1,25$ & 0,05 & 50,80 \\
\hline$W$ & 41 & 0,90 & $0,81-1,03$ & 0,04 & 33,88 \\
\hline$L$ & 59 & 1,47 & $1,36-1,68$ & 0,06 & 127,78 \\
\hline$W$ & 59 & 1,51 & $1,39-1,69$ & 0,06 & 135,41 \\
\hline$L$ & 57 & 1,42 & $1,28-1,53$ & 0,05 & 115,39 \\
\hline$W$ & 68 & 1,83 & $1,71-1,97$ & 0,05 & 230,20 \\
\hline$L$ & 38 & 0,82 & $0,68-0,91$ & 0,05 & 26,28 \\
\hline$W$ & 38 & 0,73 & $0,68-0,79$ & 0,02 & 20,30 \\
\hline
\end{tabular}

\begin{tabular}{lllllll|} 
& $n$ & $\bar{x}$ & $m i n .-m a x$. & $\sigma_{n-1}$ & $\Sigma x^{2}$ \\
\cline { 2 - 7 }$P_{4}$ & 27 & 0,81 & $0,70-0,89$ & 0,04 & 17,95 \\
$W_{1}$ & 26 & 0,62 & $0,57-0,69$ & 0,03 & 10,13 \\
\cline { 2 - 7 } & $L$ & 38 & 1,30 & $1,23-1,39$ & 0,03 & 84,99 \\
$W_{1}$ & 41 & 0,83 & $0,73-0,95$ & 0,05 & 28,70 \\
$W_{2}$ & 42 & 0,91 & $0,79-1,09$ & 0,05 & 35,52 \\
\hline$L$ & 37 & 1,32 & $1,22-1,42$ & 0,04 & 65,02 \\
$W_{1}$ & 44 & 0,90 & $0,78-1,04$ & 0,05 & 36,19 \\
$W_{2}$ & 41 & 0,94 & $0,82-1,05$ & 0,05 & 36,53 \\
\hline$L$ & 32 & 1,26 & $1,18-1,36$ & 0,04 & 51,24 \\
$M_{3}$ & 32 & 0,86 & $0,73-0,95$ & 0,04 & 24,25 \\
$W_{1}$ & 31 & 0,69 & $0,59-0,77$ & 0,03 & 14,95 \\
\hline$W_{2}$ & 31 & & & &
\end{tabular}

Table 2. - Measurements, in mm, of the teeth of Myotis nattereri from Santenay.

Mesures, en mm, des dents de Myotis nattereri de Santenay.

\begin{tabular}{l}
$C^{\circ}$ \\
\cline { 2 - 6 }
\end{tabular}

\begin{tabular}{|lllllll|}
\multicolumn{1}{c}{$n$} & $n$ & $\bar{x}$ & $\min -\max$. & $\sigma_{n-1}$ & $\sum x^{2}$ \\
\hline$P_{4}$ & 28 & 0,86 & $0,76-0,95$ & 0,04 & 20,95 \\
$W$ & 28 & 0,59 & $0,55-0,66$ & 0,02 & 10,01 \\
\hline$M_{1}$ & 21 & 1,30 & $1,26-1,38$ & 0,03 & 36,00 \\
$M_{2}$ & 22 & 0,79 & $0,72-0,93$ & 0,04 & 13,83 \\
$W_{2}$ & 22 & 0,86 & $0,78-0,96$ & 0,05 & 16,36 \\
\hline$L$ & 16 & 1,31 & $1,23-1,44$ & 0,06 & 27,65 \\
$W_{1}$ & 16 & 0,84 & $0,75-0,95$ & 0,05 & 11,50 \\
$W_{2}$ & 16 & 0,90 & $0,82-0,99$ & 0,04 & 13,13 \\
\hline$L$ & 17 & 1,27 & $1,19-1,39$ & 0,05 & 27,67 \\
$W_{3}$ & 17 & 0,87 & $0,78-1,00$ & 0,06 & 13,06 \\
$W_{2}$ & 18 & 0,70 & $0,64-0,80$ & 0,04 & 9,03 \\
\hline
\end{tabular}

Table 3. - Measurements, in mm, of the teeth of Myotis emarginatus from Santenay.

Mesures, en mm, des dents de Myotis emarginatus de Santenay.

\begin{tabular}{|c|c|c|c|c|c|}
\hline & $n$ & $\bar{x}$ & $\min . \quad \max$. & $\sigma_{n-1}$ & $\sum x^{2}$ \\
\hline L & 19 & 0,86 & $0,82-0,91$ & 0,03 & 14,06 \\
\hline w & 19 & 0,66 & $0,61-0,75$ & 0,03 & 8,45 \\
\hline L & 10 & 1,08 & $1,05-1,12$ & 0,02 & 11.73 \\
\hline$w$ & 9 & 0,95 & $0,86-1,09$ & 0,06 & 8,17 \\
\hline L & 15 & 1,26 & $1,16-1,34$ & 0,04 & 23,94 \\
\hline$w$ & 17 & 1,33 & $1,22-1,40$ & 0,05 & 30,26 \\
\hline L & 16 & 1,28 & $1,21-1,38$ & 0,04 & 26,37 \\
\hline$w$ & 19 & 1,55 & $1,41-1,66$ & 0,08 & 45,94 \\
\hline L & 7 & 0,74 & $0,69-0,79$ & 0,04 & 3,91 \\
\hline$w$ & 7 & 0,61 & $0,58-0,63$ & 0,01 & 2,65 \\
\hline
\end{tabular}

\begin{tabular}{|lccccc|}
\multicolumn{1}{c}{$n$} & $n$ & $\bar{x}$ & $\min .-\max$. & $\sigma_{n-1}$ & $\Sigma x^{2}$ \\
\hline$P_{4}$ & 6 & 0,71 & $0,68-0,76$ & 0,03 & 3,07 \\
$W_{1}$ & 6 & 0,57 & $0,55-0,59$ & 0,01 & 1,95 \\
\hline$M_{1}$ & 15 & 1,25 & $1,19-1,29$ & 0,03 & 23,75 \\
$W_{1}$ & 15 & 0,78 & $0,70-0,84$ & 0,03 & 9,33 \\
$W_{2}$ & 15 & 0,86 & $0,79-0,94$ & 0,03 & 11,28 \\
\hline$L$ & 10 & 1,27 & $1,21-1,35$ & 0,04 & 16,19 \\
$W_{1}$ & 10 & 0,83 & $0,75-0,95$ & 0,05 & 7,01 \\
$W_{2}$ & 10 & 0,88 & $0,82-0,97$ & 0,04 & 7,81 \\
\hline$L$ & 11 & 1,16 & $1,12-1,24$ & 0,03 & 14,86 \\
$W_{1}$ & 12 & 0,76 & $0,69-0,84$ & 0,04 & 6,95 \\
$W_{2}$ & 12 & 0,63 & $0,58-0,69$ & 0,03 & 4,90 \\
\hline
\end{tabular}

Table 4. - Measurements, in mm, of the teeth of Myotis brandti from Santenay.

Mesures, en mm, des dents de Myotis brandti de Santenay. 


\begin{tabular}{|c|c|c|c|c|}
\hline$n$ & $\overline{\mathbf{x}}$ & $\min .-\max$. & $\sigma_{n-1}$ & $\sum x^{2}$ \\
\hline 8 & 0,79 & $0,70-0,88$ & 0,05 & 5,04 \\
\hline 8 & 0,65 & $0,60-0,72$ & 0,03 & 3,39 \\
\hline 11 & 1,03 & $0,95-1,09$ & 0,04 & 11,73 \\
\hline 11 & 0,91 & $0,81-0,96$ & 0,05 & 9,17 \\
\hline 15 & 1,32 & $1,28-1,42$ & 0,04 & 26,37 \\
\hline 19 & 1,42 & $1,32-1,55$ & 0,05 & 38,37 \\
\hline 13 & 1,26 & $1,19-\quad, 34$ & 0,03 & 20,73 \\
\hline 13 & 1,55 & $1,44-\quad 165$ & 0,06 & 31,47 \\
\hline 4 & 0,75 & $0,74-0,77$ & & \\
\hline 4 & 0,63 & $0,61-0,66$ & & \\
\hline
\end{tabular}

\begin{tabular}{|c|c|c|c|c|c|c|}
\hline & & $n$ & $\overline{\mathbf{x}}$ & $\min .-\max$. & $\sigma_{n-1}$ & $\sum x^{2}$ \\
\hline \multirow{3}{*}{$P_{4}$} & L & 5 & 0,67 & $0,64-0,71$ & 0,03 & 2,28 \\
\hline & $w$ & 5 & 0,53 & $0,51-0,57$ & 0,03 & 1,44 \\
\hline & L & 13 & 1,19 & $1,13-1,26$ & 0,04 & 18,55 \\
\hline \multirow[t]{3}{*}{$M_{1}$} & $w_{1}$ & 13 & 0,71 & $0,66-0,76$ & 0,03 & 6,60 \\
\hline & $w_{2}$ & 13 & 0,78 & $0,75-0,83$ & 0,02 & 8,01 \\
\hline & L & 11 & 1,17 & $1,12-1,23$ & 0,03 & 15,30 \\
\hline \multirow[t]{3}{*}{$M_{2}$} & $w_{1}$ & 11 & 0,76 & $0,73-0,82$ & 0,03 & 6,48 \\
\hline & $w_{2}$ & 10 & 0,81 & $0,77-0,88$ & 0,03 & 6,65 \\
\hline & L & 13 & 1,09 & $1,02-1,13$ & 0,03 & 15,46 \\
\hline \multirow[t]{2}{*}{$M_{3}$} & $w_{1}$ & 13 & 0,70 & $0,61-0,82$ & 0,05 & 6,54 \\
\hline & $w_{2}$ & 12 & 0,59 & $0,50-0,64$ & 0,03 & 4,21 \\
\hline
\end{tabular}

Table 5. - Measurements, in mm, of the teeth of Myotis daubentoni from Santenay.

Mesures, en mm, des dents de Myotis daubentoni de Santenay.

$C^{\cdot}$\begin{tabular}{cccccc|} 
& $n$ & $\bar{x}$ & $\min . \max$. & $\sigma_{n-1}$ & $\sum x^{2}$ \\
\hline$L$ & 101 & 1,03 & $0,93-1,17$ & 0,05 & 107,89 \\
$w$ & 100 & 0,86 & $0,73-0,99$ & 0,05 & 74,51 \\
\hline$L$ & 34 & 1,23 & $1,12-1,32$ & 0,04 & 51,85 \\
$w$ & 36 & 0,98 & $0,87-1,08$ & 0,05 & 35,35 \\
\hline
\end{tabular}

Plecofus auritus

$=C^{*}$\begin{tabular}{llllll|}
\hline & $n$ & $\bar{x}$ & $\min .-\max$. & $\sigma_{n-1}$ & $\sum x^{2}$ \\
\hline$W$ & 66 & 1,10 & $1,02-1,18$ & 0,04 & 80,73 \\
\hline$L$ & 10 & 1,24 & $1,16-1,28$ & 0,03 & 15,56 \\
$W$ & 13 & 0,94 & $0,87-1,04$ & 0,04 & 11,66 \\
\hline
\end{tabular}

Plecotus oustriacus

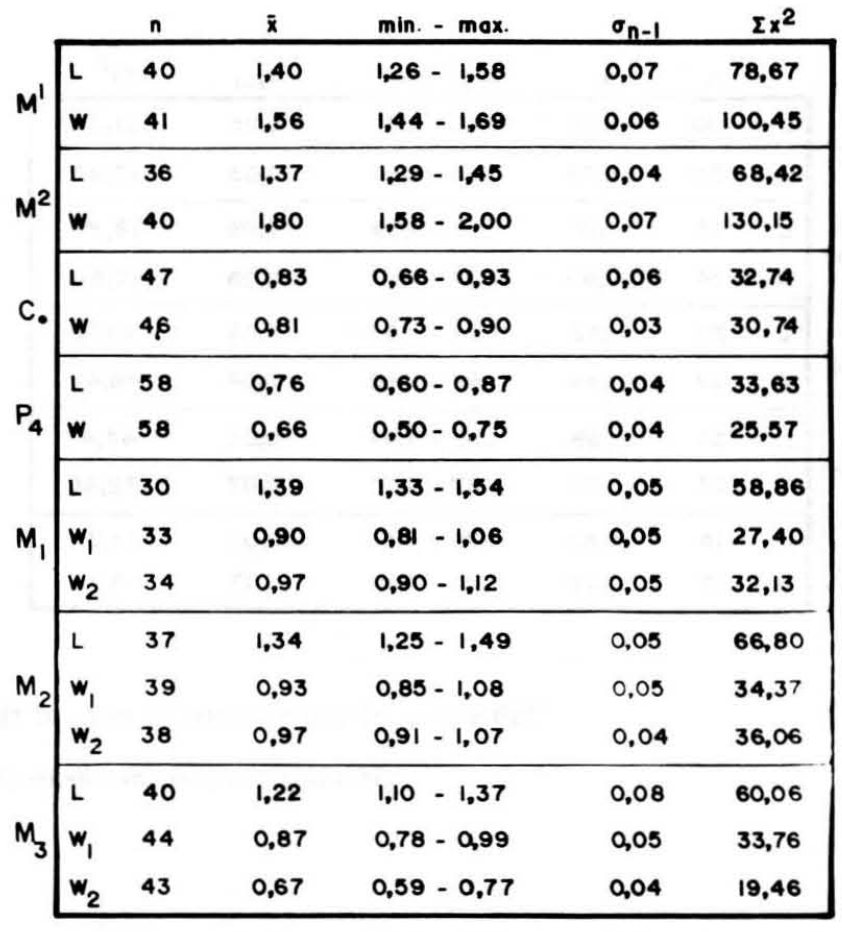

Plecotus auritus / Plecotus austriocus

Table 6. - Measurements, in $\mathrm{mm}$, of the teeth of Plecotus auritus and Plecotus austriacus from Santenay.

Mesures, en mm, des dents de Plecotus auritus et d'Plecotus austriacus de Santenay.

the morphology of the teeth of both species is similar. However, in $M$. nattereri, the canines are weaker, the upper one presents a triangular occlusal outline and the inner face is flat. The upper molars are proportionately wider and shorter. The lower teeth are narrower and with thinner cingula. The coronoid process of the mandible of the smaller species is flattened, being only slightly higher than the angular process. There is no doubt about the fact that the material of these characteristics found in Santenay belongs to $M$. nattereri and not to $M$. kretzoi
TOPAL, close to it both in size and morphology. M. kretzoi, known from the middle Pleistocene in Hungary (Topál, 1981) is somewhat larger, and the mandible, proportionately weaker, presents a lower and more rounded coronoid process than in the recent species. $M$. nattereri is nowadays distributed all over France, but not very abundant. It is found both in trees and caves, usually near rivers or lakes. As a fossil, it is known in France from several localities dating from the middle Pleistocene onwards, such as La Fage (Mein, 1975). 


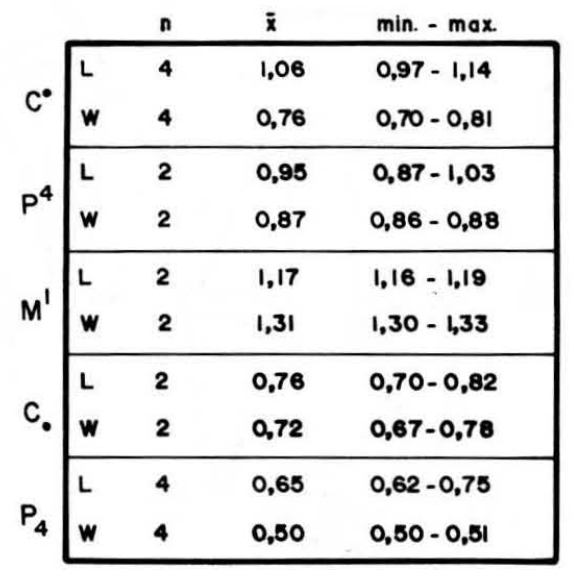

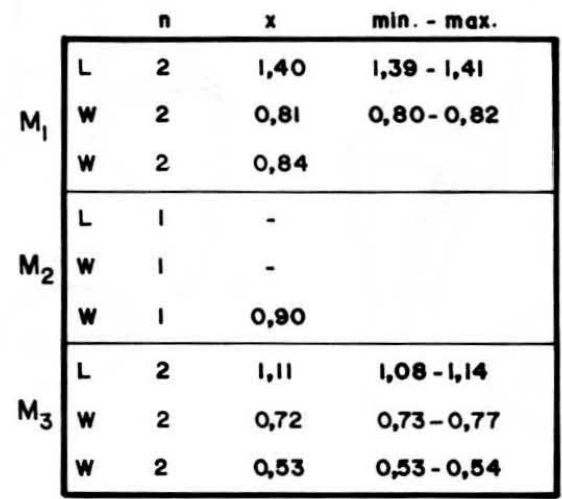

Table 7. - Measurements, in $\mathrm{mm}$, of the teeth of Barbastella barbastellus from Santenay.

Mesures, en mm, des dents de Barbastella barbastellus de Santenay.

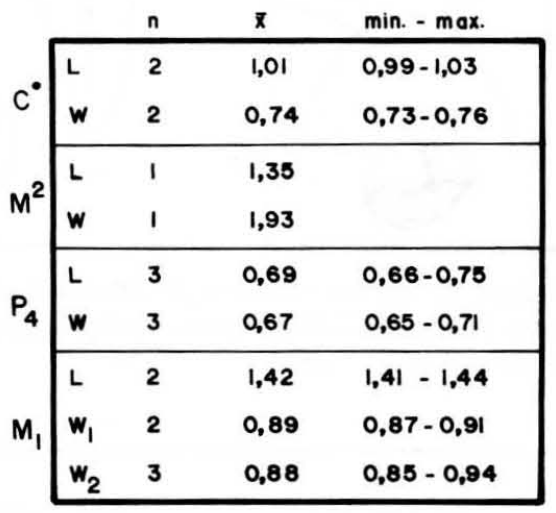

\begin{tabular}{|c|c|c|c|c|}
\hline & & $\mathrm{n}$ & $\overline{\mathbf{x}}$ & $\min .-\max$. \\
\hline \multirow{3}{*}{$M_{2}$} & L & 2 & 1,32 & $1,32-1,33$ \\
\hline & $w_{1}$ & 2 & 0,88 & \\
\hline & $w_{2}$ & 2 & 0,89 & $0,88-0,91$ \\
\hline \multirow{3}{*}{$M_{3}$} & L & 2 & 1,19 & $1,19-1,20$ \\
\hline & $w_{1}$ & 2 & 0,81 & $0,81-0,82$ \\
\hline & $w_{2}$ & 2 & 0,72 & \\
\hline
\end{tabular}

Table 8. - Measurements, in mm, of the teeth of Rhinolophus hipposideros from Santenay.

Mesures, en mm, des dents de Rhinolophus hipposideros de Santenay.

Myotis emarginatus (GEOFFROY). This species is represented in Santenay by 213 remains. It is of a similar size to $M$. nattereri. However, the teeth of both species are easily distinguished. In $M$. emarginatus, the upper canine has a long narrow cusp with one deep furrow on the labial side and another on the lingual side. In occlusal view, the outline of this tooth is oval-shaped. The upper molars have a subtriangular outline, with a strong paraloph and a distally elongated postmetacrista. The $\mathrm{P}^{4}$ has a wide and rounded talon. The lower canine is short and wide in occlusal view, and presents a narrow pointed cusp. The $\mathrm{P}_{4}$ is long and narrow. In the lower molars, the talonid is proportionately longer than in $M$. nattereri or $M$. bechsteini. This cave-dwelling species has been found in France from the middle Pleistocene onwards, though never represented by large numbers. Nowadays, it is moderately frequent and distributed all over France.

Two small Myotis species, both of similar size, are present in Santenay, Myotis brandti (EVERS-
MANN) and Myotis daubentoni (KUHL). Differences in the morphology of the mandible and isolated teeth, however, permit to distinguish between them. The upper canines of $M$. brandti present two labial furrows, absent in $M$. daubentoni. In both species, the $\mathrm{P}^{4}$ presents a cusplet at the anterolingual edge, but in $M$. brandti, this cusp is more strongly developed. The upper molars are very similar in both species; the outline in $M$. daubentoni is close to triangular and in $M$. brandti it is more rectangular. The symphysis of the mandible presents in $M$. daubentoni a ventral projection, absent in $M$. brandti. Though neither of these two species are represented by a high number of remains in Santenay ( $M$. brand$t i, 110$ remains; $M$. daubentoni, 102 remains), their presence in Santenay is very interesting for two reasons. Firstly, they have not been mentioned in any other Pleistocene locality of France, and their presence in Santenay indicates that, at least during the upper Pleistocene these two species were present in North-eastern France. Another point of interest lies 


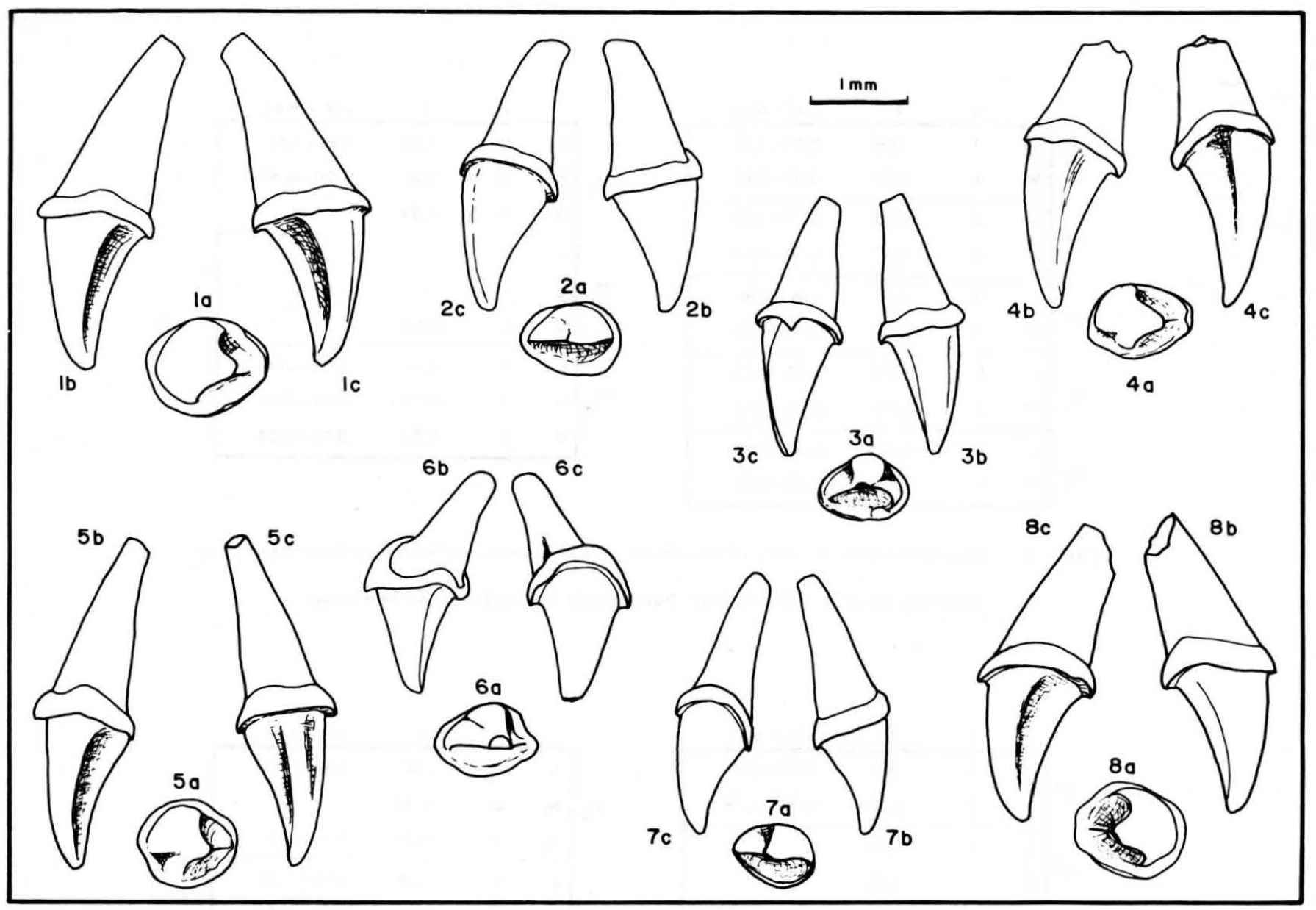

Planche 1. - Upper canines. Canines supérieures.. 1.: Plecotus austriacus. 2 : Myotis nattereri. $3:$ Myotis brandti. $4:$ Myotis emarginatus. 5 : Plecotus auritus. $6:$ Rhinolophus hipposideros. $7:$ Myotis daubentoni. $8:$ Myotis bechsteini. (a = occlusal view; $\mathrm{b}=$ labial view; $\mathrm{c}=$ lingual view. Scale $=1 \mathrm{~mm}$ ).
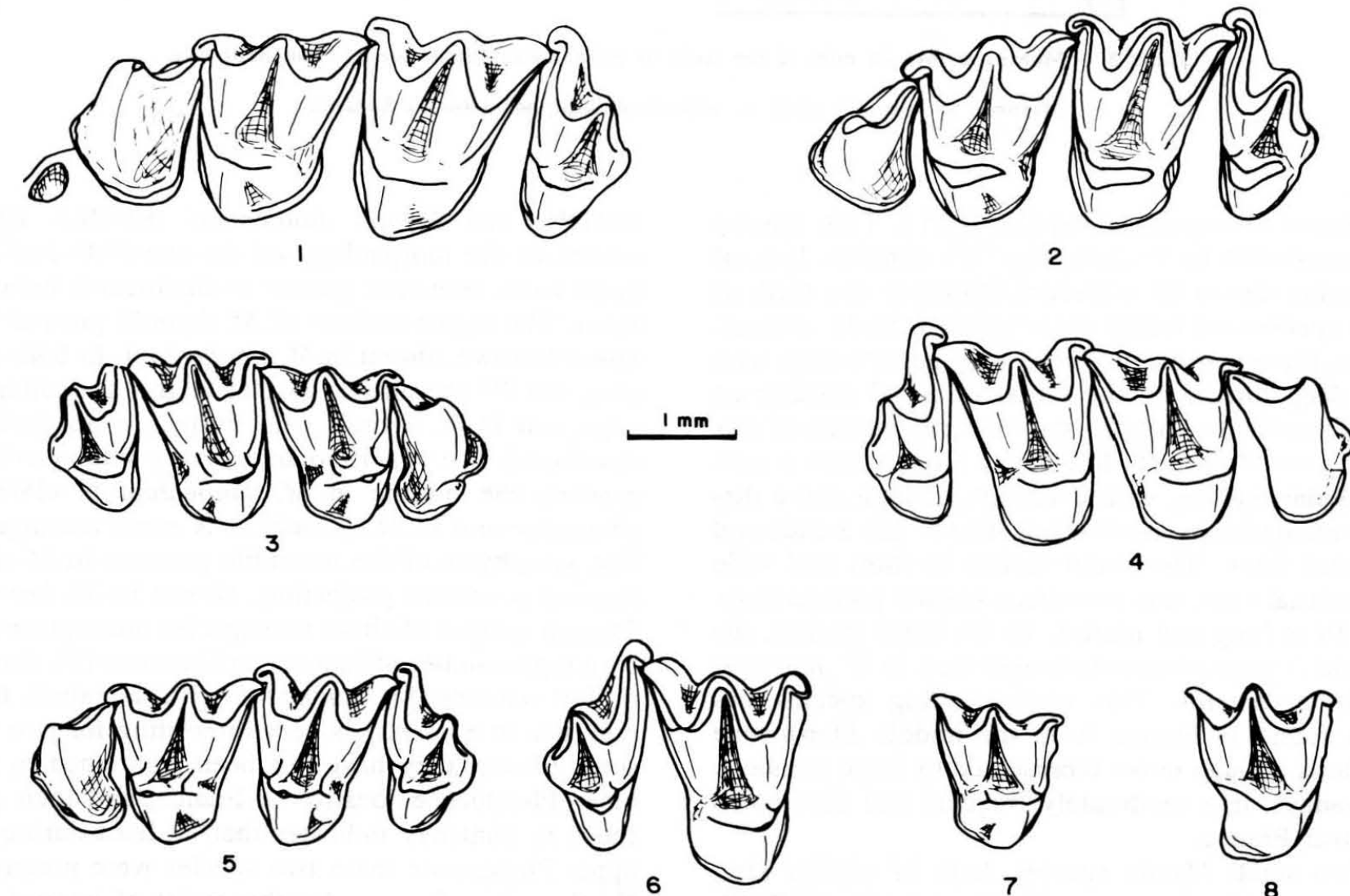

8

Planche 2. - Upper molars and $\mathbf{P}^{4}$. Molaires supérieures et $\mathrm{P}^{4} .1:$ Myotis bechsteini. $2:$ Myotis nattereri. $3:$ Myotis brandti. $4:$ Plecotus auritus. 5: Myotis daubentoni. 6 : Myotis emarginatus $\left(\mathrm{M}^{2} \mathrm{M}^{3}\right) .7:$ Barbastella barbastellus $\left(\mathrm{M}^{1}\right) .8:$ Rhinolophus hipposideros $\left(\mathrm{M}^{2}\right)$. 


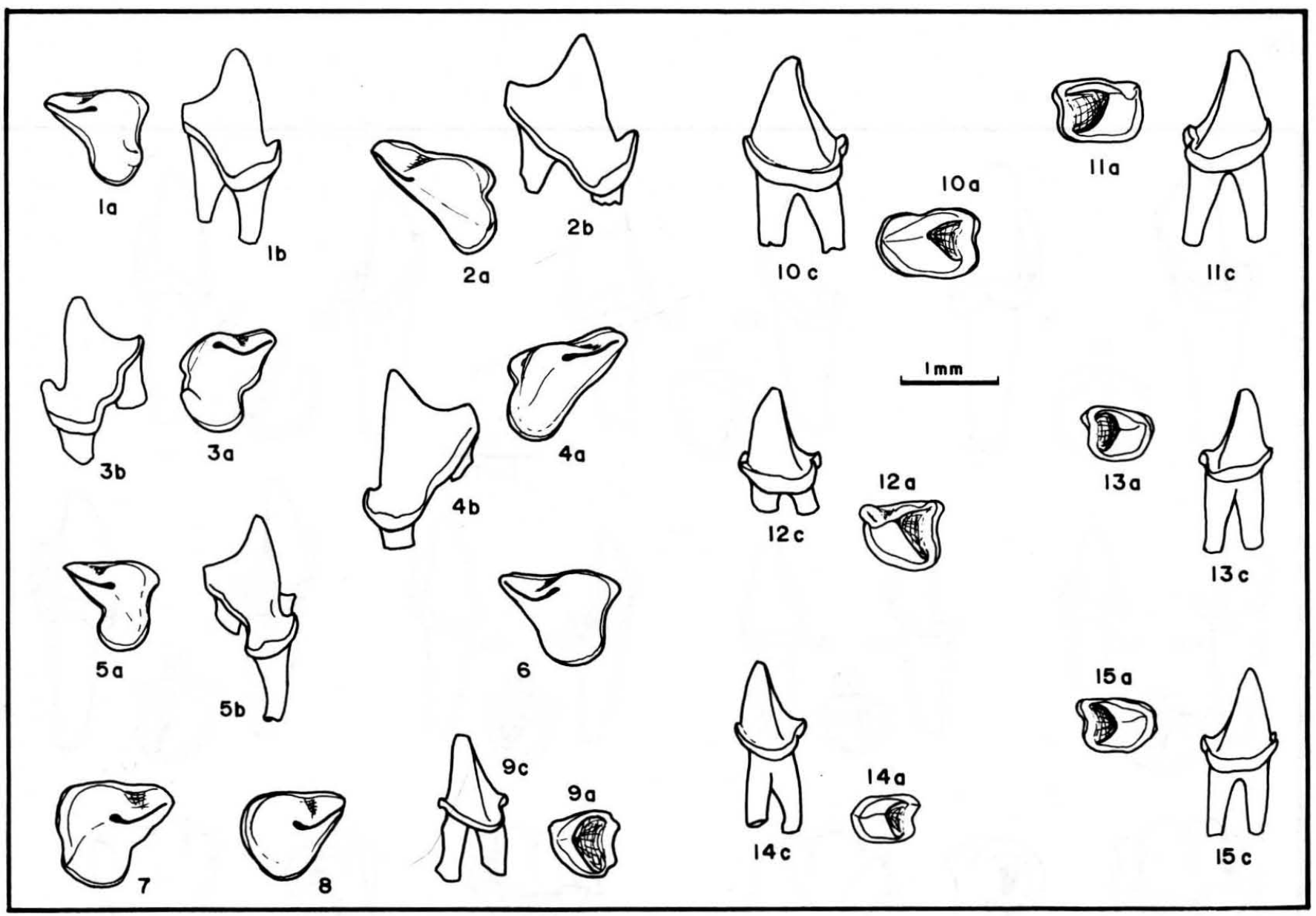

Planche 3. $-\mathrm{P}^{4} .1$ : Myotis daubentoni. 2 : Plecotus austriacus. $3:$ Myotis brandti. $4:$ Plecotus auritus. 5 : Barbastella barbastellus. 6: Myotis emarginatus. $7:$ Myotis bechsteini. $8:$ Myotis nattereri.

P4. 9 : Rhinolophus hipposideros. 10 : Myotis bechsteini. 11 : Myotis nattereri. 12 : Plecotus auritus/austriacus. $13:$ Myotis daubentoni. 14 : Barbastella barbastellus. $15:$ Myotis brandti.

$(\mathrm{a}=$ occlusal view; $\mathrm{b}=$ lingual view; $\mathrm{c}=$ labial view. Scale $=1 \mathrm{~mm}$ ).

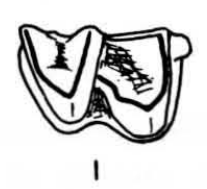

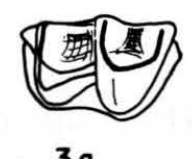

30

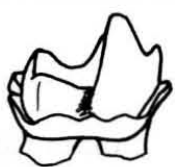

3b

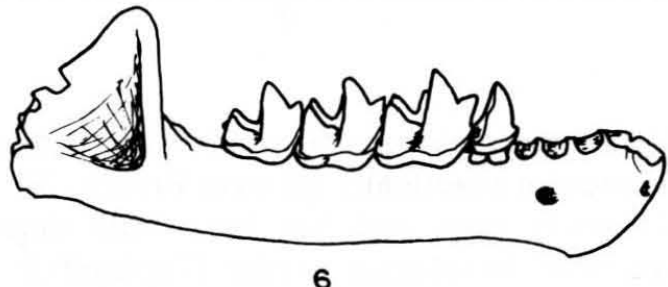

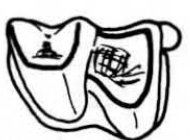

2

$\frac{1 \mathrm{~mm}}{(1,2,3,4,5)}$

$\frac{\operatorname{Imm}}{(6-10)}$

$(6-10)$

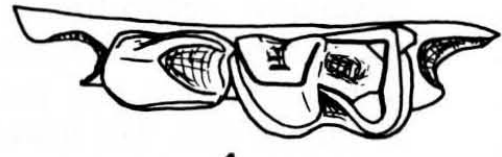

4

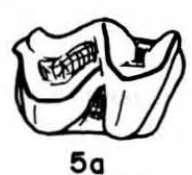

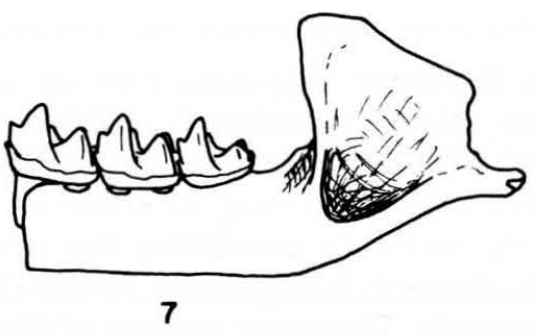

$5 \mathrm{~b}$

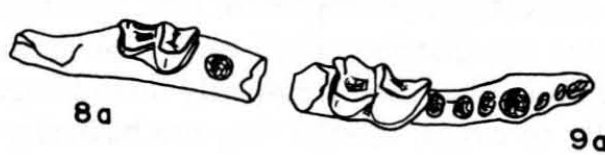

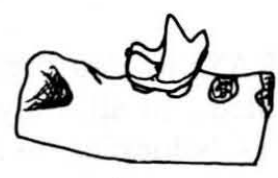

$8 \mathrm{~b}$
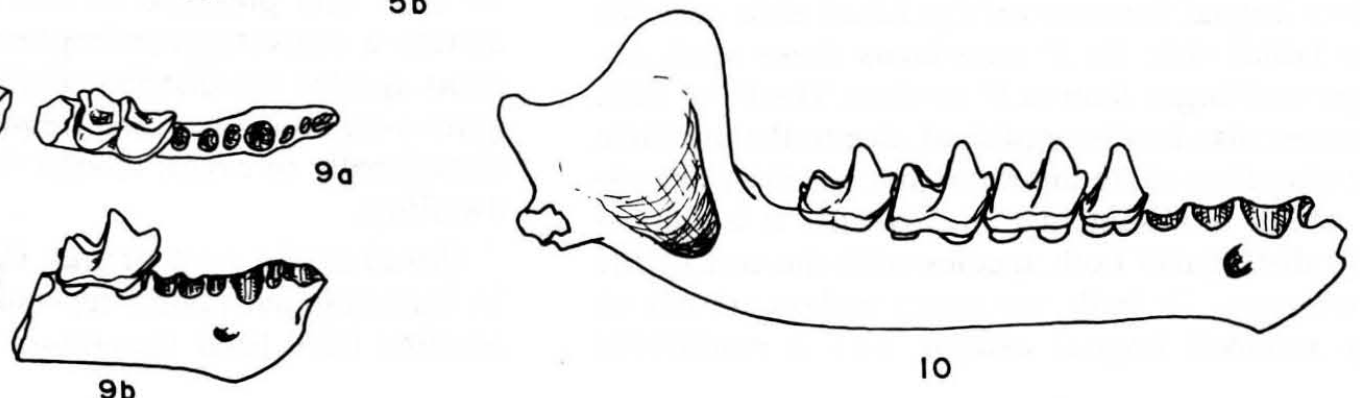

Planche 4. - Lower canines. Canines inferieures. 1 : Myotis bechsteini. $2:$ Myotis emarginatus. $3:$ Myotis nattereri. $4:$ Myotis daubentoni. 5: Myotis brandti. $6:$ Barbastella barbastellus. 7 : Plecotus auritus/austriacus. $(\mathrm{a}=$ occlusal view; $\mathrm{b}=$ labial view; $\mathrm{c}=$ distal view. Scale $=1 \mathrm{~mm})$. Humera. 8 : Myotis bechsteini. 9 : Myotis emarginatus/nattereri/daubentoni. $(\mathrm{d}=$ external view; $\mathrm{e}=$ posterior view; $\mathrm{f}=\mathrm{internal}$ view. Scale $=1 \mathrm{~mm})$. 
species. The $\mathrm{P}^{4}$ of this species is small, with a welldeveloped heel and without cingular cusplets, and cannot be taken for the $\mathrm{P}^{4}$ of Rhinolophus hipposideros, another species present in Santenay, and of similar size and morphology, because of the anterolabial expansion of the cingulum, absent in $R$. hipposideros. The $\mathbf{M}^{1}$ is subrectangular, with paraloph and metaloph. The lower teeth present thin cingula. The morphology of the lower canines resembles that of the lower canines of Plecotus, but are conspicuously smaller. The $\mathrm{P}_{4}$ is small, with pentagonal outline in occlusal view. The lower molars are nyctalodont. The size and morphology of the material found in Santenay agrees entirely with that of recent $B$. barbastellus. Thus, it cannot be taken for Barbastella rostrata TOPAL, described from middle Pleistocene deposits from Hungary, which is larger and presents several morphological differences with the recent species (Topal, 1970). Barbastella barbastellus is known in France from the middle Pleistocene onwards. It is distributed all over France, sometimes found in caves during winter, especially in cold regions. In summer and in warmer regions, it is more frequently found in trees.

Rhinolophus hipposideros (BECHSTEIN) is the only Rhinolophus species found in Santenay. It is represented by a low number of remains $(n=13)$. The upper canines of this species present the typical morphology of the genus Rhinolophus, with a irregular labial cingulum, and the root forming an angle with the crown. The $\mathrm{M}^{2}$ is easily recognised by its very short talon and postprotocrista joining the distal cingulum. The $\mathrm{P}_{4}$ is triangular in occlusal outline. The lower molars are nyctalodont and with longer talonids than in Barbastella. In spite of the low number of remains, the possibility of their belonging to the Pliocene species Rhinolophus variabilis TOPAL, very close both in size and morphology, is out of question. $R$. variabilis presents larger heels in the upper molars, the lower teeth are orocaudally elongated and the tip of the cusp of the $\mathrm{P}_{4}$ is bent in mesial direction, instead of straight as in $R$. hipposideros (Topal, 1975). The oldest fossil record of $R$. hipposideros in France dates from the Upper Pleistocene localities of L'Hortus (Jullien, 1972 b) and Fontéchevade (Schreuder, 59). It is distributed nowadays all over France, never forming large colonies and frequently found in caves.

\section{RESULTS}

The bat fauna in Santenay is very important for the knowledge of the history of this fauna in France. It is unique from the point of view of the association of species present, not similar to any other asso- ciation described in the French Pleistocene up to now. The dominating species is Myotis bechsteini. Though the abundance of this species in the present is low, it was very frequent during all the Pleistocene, judging from the fossil data, dominating in some localities, as in the French middle Pleistocene locality of La Fage (Mein, 1975). The other two abundant Myotis species of Santenay, M. nattereri and $M$. emarginatus are also frequent in Pleistocene localities. However, neither of the large Myotis species, $M$. myotis or $M$. blythi, are present in Santenay. This is surprising, as either one or the other species are practically always present in Quaternary localities. In contrast, $M$. brandti and $M$. daubentoni, both present in Santenay, are rarely found in Quaternary deposits.

Another interesting fact in Santenay is the high representation of species which, though mainly treedwelling ( $M$. bechsteini, $M$. emarginatus, $P$. auritus and $B$. barbastellus), occasionally take refuge in caves either during cold seasons or in cold regions. This fact, together with the absence of termophilous species such as $M$. blythi, $R$. euryale, $R$. mehelyi or Miniopterus schreibersi, present in other French Pleistocene localities, seems to indicate the Santenay deposit took place in a relatively cold period. The presence of $M$. brandti seems to support this interpretation, as its present distribution is more to the North and East in Europe. In a cold period, this species might have pushed its distribution southwards and westwards.

It is interesting, however, to note that the diversity of the bat fauna in Santenay has a high value $(\mathrm{H}=2,46$ by Shannon-Weaver's index). This might indicate that in fact the material comes from a climatic transition, that is, either the beginning or the end of a cold phase.

The paleoclimatic interpretation obtained with the bat fauna agrees with Chaline's interpretation (1972), in which a change from temperate and relatively mild to cold climate is observed in the fissure-filling, corresponding to the end of the Riss-Würm to the beginning of the Würm I. The peculiarity of the association would be due to the fact of belonging to a transitional period, in which certain termophilous species persist (P. austriacus) when already relatively "cold" species ( $M$. brandti) have moved into the area, increasing the diversity.

Aknowledgements. - I am indebted to Dr. Chaline, who kindly lent me the bat material of the locality of Santenay for this study. Dr. P. Mein from the University of Lyon made useful comments over the manuscript, which led to its improvement. This paper is a part of the research results obtained during a ten months' stay in the Centre des Sciences de la Terre of the University of Bourgogne. This stay was financed by the PFPI program of the Spanish MEC in collaboration with the French MRC. 


\section{BIBLIOGRAPHY}

Chaline, J. (1972) - Les Rongeurs du Pléistocène moyen et supérieur de France. Cahiers de Paléontologie. Edit. du CNRS. Paris. 410 p., 17 plates.

Fayard, A. (ed.) (1984) - Atlas de Mammifères sauvages de France. Societé Française pour l'étude et la Protection des Mammifères, Paris, 299 p.

Jullien, R. (1972 a) - Les Chiroptères des couches paléochrétiennes de la grotte de L'Hortus (Valflaunès, Hérault). Etudes Quaternaires, Paris, 1, 267-269.

Jullien, R. (1972 b) - Les Chiroptères du Würmien II de la Grotte de l'Hortus (Valflaunès, Hérault). Etudes Quaternaires, Paris, 1, 247-265.

Mein, P. (1975) - Les Chiroptères (Mammalia) du gisement pléistocène des Abimes de la Fage à Noailles (Corrèze). Nouv. Arch. Mus. Hist. Nat. Lyon, 13, 57-67.

Menu, H. \& Popelard, J.B. (1987) - Utilisation des caractères dentaires pour la détermination des Vespertilioninés de l'Ouest européen. Le Rhinolophe, Genève, 4, 88 p.

Schreuder, A. (1959) - La Grotte Fontéchevade : Les Micromammifères. Arch. Inst. Paléont. hum. Paris, 29, 230-240.

Sevilla, P. (1988) - Estudio paleontológico de los Quirópteros del Cuaternario español. Paleontologia $i$ Evolucio, Sabadell, 22, 113-233.
Sevilla, P. \& Lopez-Martinez, N. (1986) - Comparative systematic value between dental and external/skeletal features in Western European Chiroptera. In : Teeth Revisited: Proceedings of the VIIth International Symposium on Dental Morphology, Paris 1886. Russell, D. E., Santoro, J.P. \& Sigogneau-Russell, D., eds. Mém. Mus. Hist. nat. Paris, (série C), 53, 255-266.

Sigé, B. (1968) - Les Chiroptères du Miocène inférieur de Bouzigues. I. Etude systématique. Palaeovertebrata, Montpellier, 8 (II-IV), 243-268.

Topal, G. (1970) - Barbastella rostrata $\mathrm{n}$. sp. from the middle Pleistocene of the Tarkö niche, North-East Hungary. Discussiones paleontologicae, Budapest, 15, 5-18.

Topal, G. (1975) - A new fossil horseshoe bat (Rhinolophus variabilis $\mathrm{n}$. sp.) from the Pliocene sediments of the Osztramos Hill, NE Hungary (Mammalia, Chiroptera). Fragm. Min. et Paleont., Budapest, 6, 5-29.

Topal, G. (1981) - New fossil Mouse-eared bat, Myotis kretzoii sp. n., from the middle Pleistocene of Hungary (Mammalia : Chiroptera). Fragm. Min. et Paleont., Budapest, 10, 59-64.

Tupinier, Y. \& Aellen, V. (1978) - Présence de Myotis brandti (Eversmann, 1845) (Chiroptera) en France et en Suisse. Revue suisse de Zoologie, Genève, 85 (2), 449456. 